\title{
Menumbuhkan Jiwa Kewirausahaan Pemuda Melalui Program KKN PPM di Kampung Pujokerto Kecamatan Trimurjo
}

\author{
Diterima: 04 Januari 2021 \\ Direview: 06 Januari 2021 \\ Disetujui: 06 Februari 2021
}

\author{
Andiana Rosid ${ }^{1 *}$, Yateno $^{2}$, Jawoto Nusantoro ${ }^{3}$ \\ Program Studi D3 Perbankan dan Keuangan, Universitas Muhammadiyah Metro ${ }^{1}$ \\ Program Studi Manajemen, Universitas Muhammadiyah Metro ${ }^{2}$ \\ Program Studi Akutansi, Universitas Muhammadiyah Metro3
}

Email: rasydande@gmail.com

\begin{abstract}
Abstrak
Salah satu agenda utama bagi pembangunan nasional adalah sektor ekonomi, khususnya kewirausahaan. Oleh karena itu, pada beberapa skim pengabdian kepada masyarakat peningkatan sektor kewirausahaan atau UMKM digalakkan untuk dapat dikembangankan kepada masyarakat. Harapannya, dengan munculnya pewirausahapewirausaha baru, sektor ekonomi masyarakat tumbuh dan semakin mapan, maka sektor lainya seperti pendidikan dan kesehatan dapat semakin terjamin. Berbagai pihak diharapkan menjadi agent of change bagi peningkatan di sektor ekonomi dan UMKM ini. Melalui program KKN PPM, tim Universitas Muhammadiyah Metro mencoba menjadi agen untuk menumbuhkan pewirausaha-pewirausaha baru dengan target khusus yaitu pemuda-pemudi di Kampung Pujokerto Kecamatan Trimurjo Lampung Tengah. Alasan dipilihnya lokasi ini adalah karena sebagian besar pemuda dan pemudi di Kampung ini merupakan petani turun temurun, yang dipandang dari sisi orientasi kewirausahaannya masih cukup rendah. Metode yang dilaksanakan pada pengabdian ini adalah pendekatan secara personal, FGD, studi banding, dan pelaksanaan kewirausahaan. Hasil pengabdiannya adalah terbentuknya kelompok kewirsausahaan berbasis pemuda yang diberinama Usaha Muda Mudi Mandiri (UM3) dan terciptanya usaha bagi kelompok berupa budi daya pembesaran dan pembenihan ikan lele, serta pelatihan pembuatan souvenir pernikahan berbahan Tali Kur.

Kata Kunci: Kewirausahaan berbasis Pemuda, Kelompok wirausaha pemuda, KKN PPM

\section{Abstrak}

One of the main agendas for national development is the economic sector, especially entrepreneurship. Therefore, in some community service schemes, the entrepreneurship sector or MSME sector enhancement is encouraged so that it can be developed in the community. The hope is that with the emergence of new entrepreneurs, the economic sector of society will grow and become more established, so that other sectors such as education and health can be more secure. Various parties are expected to become agents of change for improvement in the economic sector and MSMEs. Through the KKN PPM program, the University of Muhammadiyah Metro team tries to become an agent to grow new entrepreneurs with a special target, namely young people in Pujokerto Village, Trimurjo District, Central Lampung. The reason for choosing this location is because most of the youth and girls in this village are hereditary farmers, which is considered from the perspective of their entrepreneurial orientation is still quite low. The method used in this service is a personal approach, FGD, comparative studies, and the implementation of entrepreneurship. The result of this dedication was the formation of a youth-based entrepreneurship group called Usaha Muda Mudi Mandiri (UM3) and the creation of a business for the group in the form of raising and hatching catfish, as well as training in making wedding souvenirs from Tali Kur. Keywords: Youth-based entrepreneurship, youth entrepreneur groups, KKN PPM
\end{abstract}

\section{PENDAHULUAN}

Kewirausahaan merupakan salah satu pondasi bagi upaya peningkatan keseahteraan masyarakat, khususnya bagi masyarakat pedesaaan untuk dapat meningkatkkan kesejahteraan sektor ekonomi dan kemudian diharapkan dapat menjadi jembatan bagi peningkatan di sektor pendidikan dan kesehatan di masyarakat. Jika dirunut kembali, hal ini sesuai dengan program 
Nawacita yang digaungkan oleh pemerintah pada butir ke tiga yaitu upaya pembangunan Indonesia dari pinggiran dan pedesaan serta butir ke lima yaitu program Indonesia pintar serta peningkatan kesejahteraan masyarakat (Tim PresidenRI.go.id, 2016; hal 55).

Sesuai dengan tujuan tersebut oleh karena itu hibah KKN PPM dari Kemenristek Dikti dapat menjadi salah satu sarana yang tepat untuk menyelesaikan berbagai persoalan yang ada di desa-desa. Hal ini dikarenakan syarat dari KKN PPM mengharuskan lokasi KKN PPM haru desa atau kampung yang notabene pembanguan serta kesejahteraan masyarakatnya masih tertinggal dibandingkan dengan masyarakat di perkotaan.

Pengabdian ini merupakan salah satu program tambahan dari sebuah kesatuan program KKN PPM yang mengangkat tema peningkatan daya saing industri penggilingan padi di kampung Pujokerto dan Pujobasuki Kecamatan Trimurjo (Jawoto, Yateno, \& Rosid, 2018), dimana masalah utama yang diangkat adalah terkait permasalahan daya saing industri penggilingan padi yang semakin menurun (Rosid \& Sobirin, 2015). Pemasalahan lain yang ada di Kecamatan Trimurjo khususnya Kampung Pujokerto Dusun 1 Srimulyo adalah, sebagian besar remaja yang ada di Dusun tersebut masuk dalam kategori pengangguran. Hal ini dikarenakan banyak dari mereka bekerja membatu keluarga di sawah, atau dengan kata lain sawah tersebut masih milik keluarga, dan disisi lain mereka tidak memiliki pekerjaan formal atau tetap, ataupun berwirausaha selain menjadi petani. Sebagian besar dari remaja ini merupakan lulusan setingkat SLTA, dan aktivitas yang mereka lakukan setelah selesai membantu keluarga hanya berkumpul di perempatan jalan tanpa tujuan yang jelas. Hal ini diperparah dengan tidak aktifnya kegiatan kepemudaan seperti Karang Taruna atau kelompok pemuda wirausaha yang dapat menaungi, dan menyerap ide-ide kreatif dari pemuda-pemudi di Kampung tersebut.

Oleh karena itu, untuk menyelesaikan masalah atau meminimalisir pengangguran remaja yang ada di dusun Srimulyo Kampung Pujokerto Kecamatan Trimurjo tersebut, tim dari Universitas Muhammadiyah Metro melalui hibah KKN PPM tahun 2018 menawarkan untuk memberikan pendampingan kepada para pemuda pemudi di Kampung Pujokerto untuk menjadi pemuda mandiri dan berkarya melalui inisiasi pembentukan organisasi atau kelompok pemuda berwirausaha

\section{METODE PELAKSANAAN}

Untuk melaksanakan program kewirausahaan berbasis kepemudaan kepada warga di pedesaaan ternyata tidak semudah yang dibayangkan. Ketakutan untuk gagal dan minimnya 
modal menjadi alasan utama bagi pemuda pemudi ini untuk tidak memulai usaha mereka. selain itu, kultur petani yang sangat kuat menyebabkan pemuda-pemuda pemuda ini cenderung malas unuk memulai bisnis. Oleh karena itu dibutuhkan beberapa metode untuk melaksanakan proram kewirausahaan bagi pemuda ini. Beberapa metode yang dilaksanakan oleh Tim KKN PPM Universitas Muhammadiyah Metro diantaranya:

\section{a. Pendekatan secara personal}

Untuk menjaring minat serta kemauan pemuda untuk bergabung dan mendirikan sebuah usaha milik bersama (kelompok) di Kampung Pujokerto, dibutuhkan upaya pendekatan secara personal kepada beberapa pemuda. Alasan utamanya adalah, mereka tidak terbiasa berkumpul dalam sebuah prosesi yang bersifat formal kepemudaan. Umumnya kegiatan formal yang diikuti oleh para pemuda di kampung ini adalah kegiatan yang bersifat keagamaan, dan sebagian besar peran dari mereka hanya sebagai peserta, bukan panitia atau petugas. Budaya Senioritas dan mendahulukan yang tua sangat kental di Kampung ini, bahkan belum ada kegiatan yang sifatnya pengkaderan sebagai generasi penerus desa.

Untuk mesiasati kondisi ini, tim KKN PPM mendapatkan saran dari tokoh desa untuk menunjuk beberapa pemuda yang ditugaskan untuk menjadi perekrut anggota kelompok kepemudaan tersebut.

\section{b. Rapat Pemuda melalui pendekatan FGD}

Setelah berhasil mengumpulkan anggota pemuda di Kampung Pujokerto, tahap selanjutnya adalah melaksanakan rapat pemuda kepemudaan dengan metode Focus Discussion Group (FGD) yang diberi tema menumbuhkan jiwa kewirausahaan pemuda Dusun 1 Kampung Pujokerto. Pada pertemuan ini, FGD fokus pada penjaringan ide-ide kewirausahaan yang mungkin dapat dikembangkan di Kampung tersebut. Dari pertemuan ini diperoleh kesepakatan bahwa ide usaha yang akan dijalankan adalah sektor perikanan budidaya pembesaran lele, sedangkan bagi pemudi-pemudi akan diberikan pelatihan ketrampilan pembuatan souvenir.

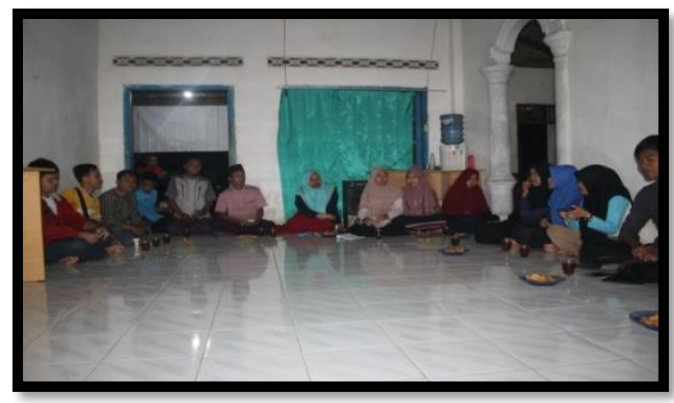

Gambar 2: FGD inisiasi pembentukan kelompok usaha berbasis pemuda Dusun Srimulyo Kampung Pujokerto 
Alasan dipilihnya usaha pembesaran ikan lele adalah; pertama, lokasi dusun Srimulyo kampung Pujokerto berada disepanjang aliran irigasi utama Kecamatan Trimurjo, sehingga memudahkan akses untuk pengisian air kolam. Kedua, usaha pembesaran ikan lele tidak membutuhkan ilmu yang terlalu rumit untuk memulainya, sehingga siapa saja dapat memulai usaha budidaya ikan lele ini. Telah dibuktikan oleh hasil pengabdian sebelumnya bahwa usaha budidaya lele tersebut dapat berjalan dan menghasilkan (Nusantoro, et al 2018). Ketiga, modal yang dibutuhkan tidak terlalu besar, dan keempat pemasaran ikan lele lebih mudah, dan waktu yang dibutuhkan untuk pembesaran relatif lebih singkat dibandingkan dengan budidaya ikan lainnya.

Dari hasil FGD ini pula diperoleh kesepakatan bahwa media budidaya pembesaran ikan lele menggunakan kolam keruk dilapisi dengan terpal. Alasan dipilihnya media terpal karena dianggap lebih mudah dalam proses pemanenan ikan, serta tidak mudah bocor atau air meresap ke dalam tanah. Sedangkan untuk varietas ikan lele yang dipilih adalah benih ikan lele varietas mutiara. Pemilihan ikan jenis ini berdasarkan saran dari beberapa mahasiswa biologi yang menurut banyak testimony memiliki daya tahan yang lebih baik serta lebih cepat dibandingkan dengan varietas ikan lele lainnya.

Dari hasil FGD ini pula, dibentuk organisasi kewirausahaan pemuda dengan nama Usaha Muda Mudi Madiri (UM3) dengan struktur organisasi Firdaus (Ketua), Nila (wakil ketua), Alfian (Bendahara), dan Nurrohman (Pemasaran), dan Muslih (Humas). Pemilihan ketua dan perangkat UM3 dilakukan dengan cara metode voting yang sudah disepakati oleh seluruh anggota pemuda dan pemudi dusun Srimulyo Kampung Pujokerto Kecamatan Trimurjo Lampung Tengah.

\section{Pelaksanaan Kegiatan}

Pelaksanaa program kewirausahaan berbasis kepemudaan melalui KKN-PPM 2018 di dusun Srimulyo Kampung Pujokerto kecamatan Trimurjo ini secara umum dibagi menjadi 3 program utama yaitu:

- Rekrutmen anggota dan pembentukan struktur organisasi

- Pembuatan kolam dan pengelolaan budidaya ikan lele

- Pemanenan dan evaluasi

- Pelatihan ketrampilan tangan 


\section{HASIL, PEMBAHASAN, DAN DAMPAK}

\section{Pembuatan Kolam dan pembudidayaan ikan lele}

Seperti yang sudah dihasilkan dalam tahap FGD sebelumnya, bahwa media kolam budidaya ikan lele menggunakan terpal, dengan ukuran 6x8 meter. Dalam pengerjaanya, kolam dibuat secara gotong royong oleh pemuda UM3 dan mahasiswa KKN PPM UM Metro.
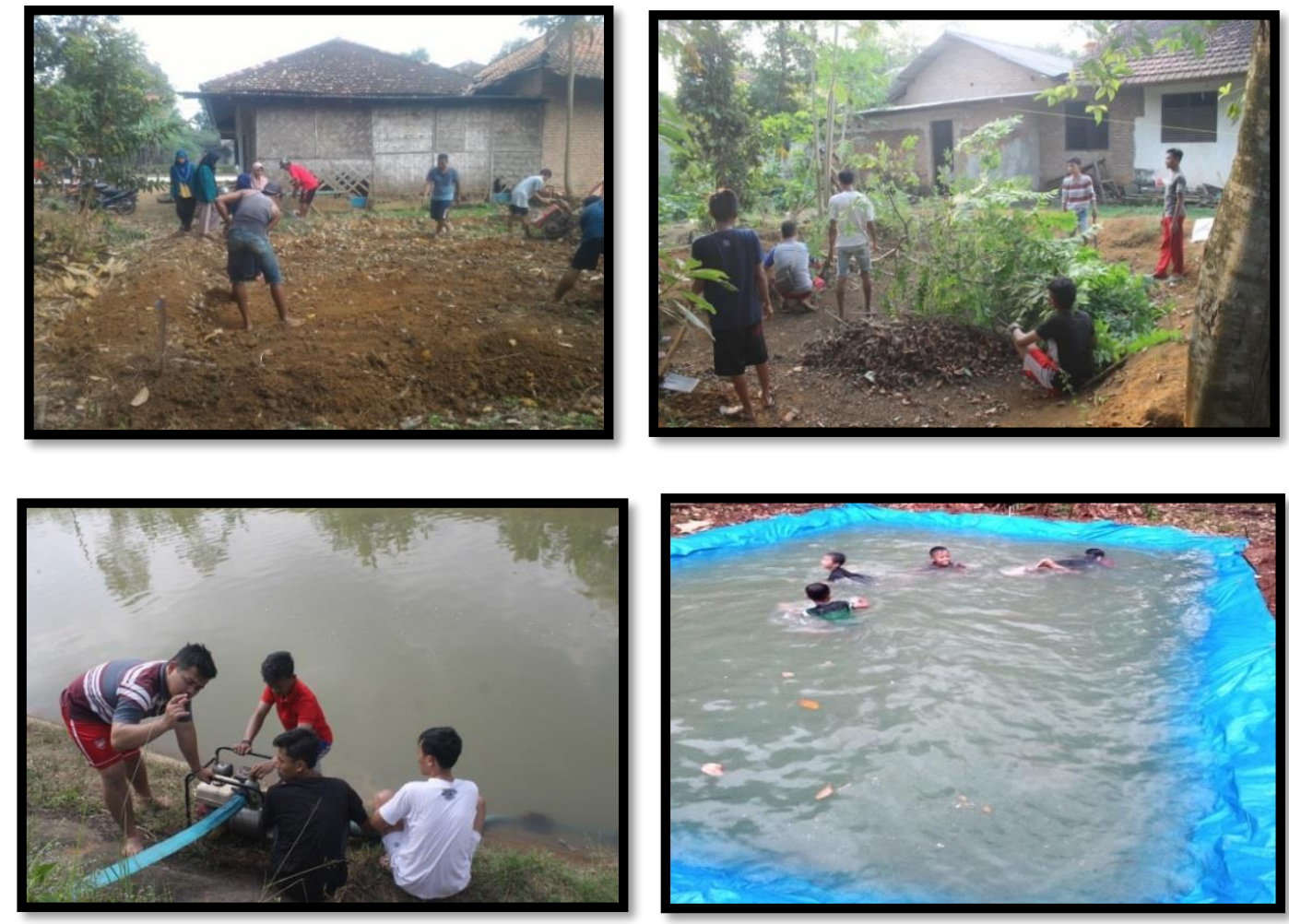

Gambar 2. Pembuatan 2 kolam dan pengisian air

Setelah kolam jadi kemudian di isi air dengan menggunakan pompa air yang dialirkan dari irigasi primier tidak jauh dari lokasi kolam milik UM3. Setelah air terisi, didiamkan selama 3 hari sebelum kemudian ditebar benih ikan lele sebanyak 6000 ekor untuk masing-masing kolam. Pemberian pakan dilakukan oleh pemuda UM3 dan piket sudah terjadwal.
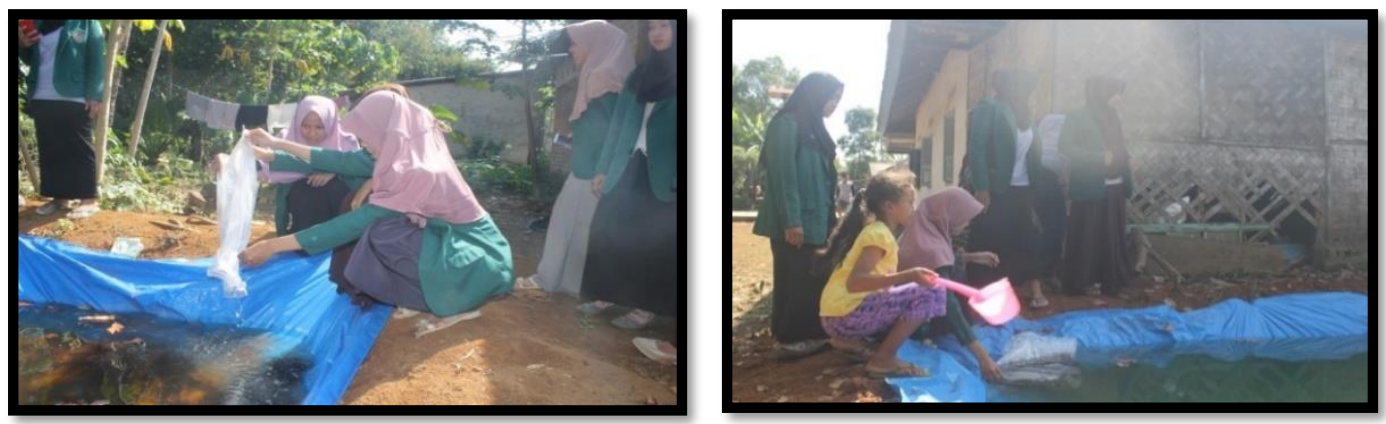

Gambar 3. Penebaran benih ikan lele mutiara 


\section{Sortasi dan Pemanenan ikan lele}

Dikarenakan pada saat pelaksanaan budidaya ikan lele ini sedang dalam musim kemarau dan matahari sangat terik, maka tingkat kematian ikan lele cukup tinggi. Dengan insting bisnis yang mulai menguat, anggota UM3 berinisiatif menanyakan langsung kepada pembudidaya dari desa lain yang lebih senior, dan mendapatkan saran agar air dalam kolam harus diganti. Selama proses budidaya ikan lele ini UM3 telah mengganti air di kolamnya sebanyak 2 kali, dan terbukti tingkat kematian menurun signifikan.

Setelah berusia kurang lebih 2 bulan, dan dirasa ukuranya sudah pas untuk dijual, maka tahap selanjutnya adalah pemanenan lele. Proses pemanenan dilakukan secara gotong royong oleh anggota UM3. Dan untuk melatih mental berdagangnya, tim KKN PPM memberikan tantangan kepada UM3 agar lele yang dipanen harus dijual kepada konsumen secara langsung dengan metode tradisional dari pintu ke pintu, serta pemasaran melalui media sosial untuk memberitahukan kepada teman-teman anggota UM3. Meskipun tidak banyak yang bisa dijual kepada konsumen langsung, namun dengan Dengan metode ini ternyata pejualan lele berhasil meningkatkan margin dibandingkan jika dijual ke pengepul. Sebagian besar ikan hasil panen dijual ke pengepul, dan masih tersisa ikan sortiran yang belum sesuai ukuran standar jual ditampung kembali ke kolam untuk dibesarkan sesuai ukuran yang layak jual.
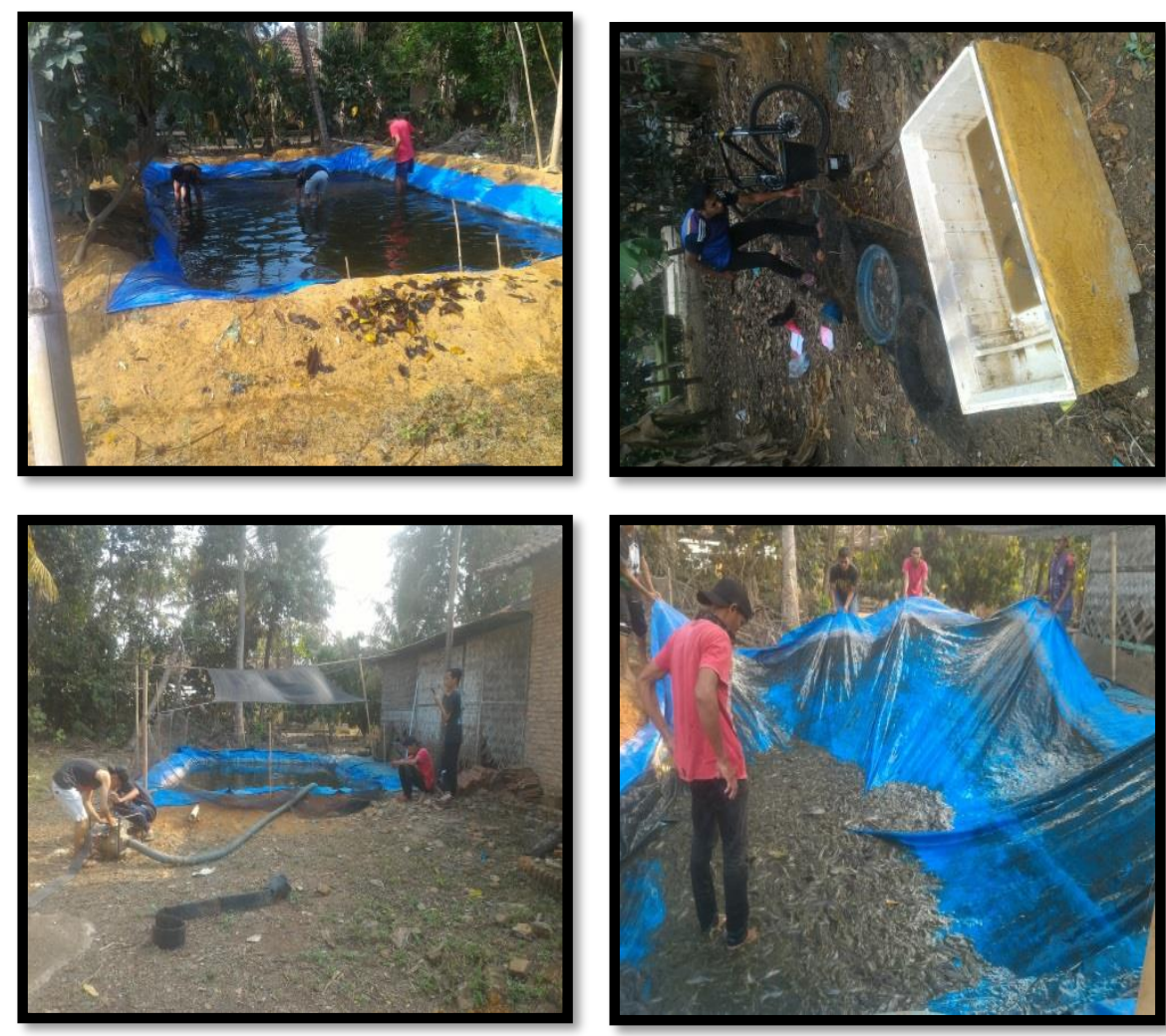

Gambar 4. Proses Pemanenen ikan Lele di dua kolam oleh UM3 


\section{Pelatihan Pembuatan Kerajinan Souvenir berbahan Tali Kur}

Untuk meningkatkan ketrampilan sekaligus meningkatkan perekonomian warga, Tim KKN PPM UM Metro memiliki ide untuk memberikan pelatihan pembuatan souvenir berbahan dasar Tali kur kepada ibu-ibu KWT sekaligus Pemudi UM3. Pelatihan kerajinan ini rangka memanfaatkan peluang yang dimiliki oleh ibu-ibu dan pemudi UM3 yaitu masih banyak waktu luang yang dimiliki. Selain itu untuk membuat kerajinan dari tali kur ini dapat dikatakan cukup mudah, serta bahan bakunya murah dan mudah di dapat di pasar Metro.

Peluang dai segi bisnis yaitu trend permintaan masyarakat pada produk souvenir juga semakin meningkat untuk acara-acara pernikahan maupun acara lainnya. Untuk bentuk awal dalam pelatihan souvenir dari tali kur ini adalah bentuk udang dan topi. Pada saat itu juga ada pesanan dari salah satu warga yang hendak melangsungkan pernikahan, dan produk souvenir ini mendapatkan sambutan yang sangat baik dari warga.
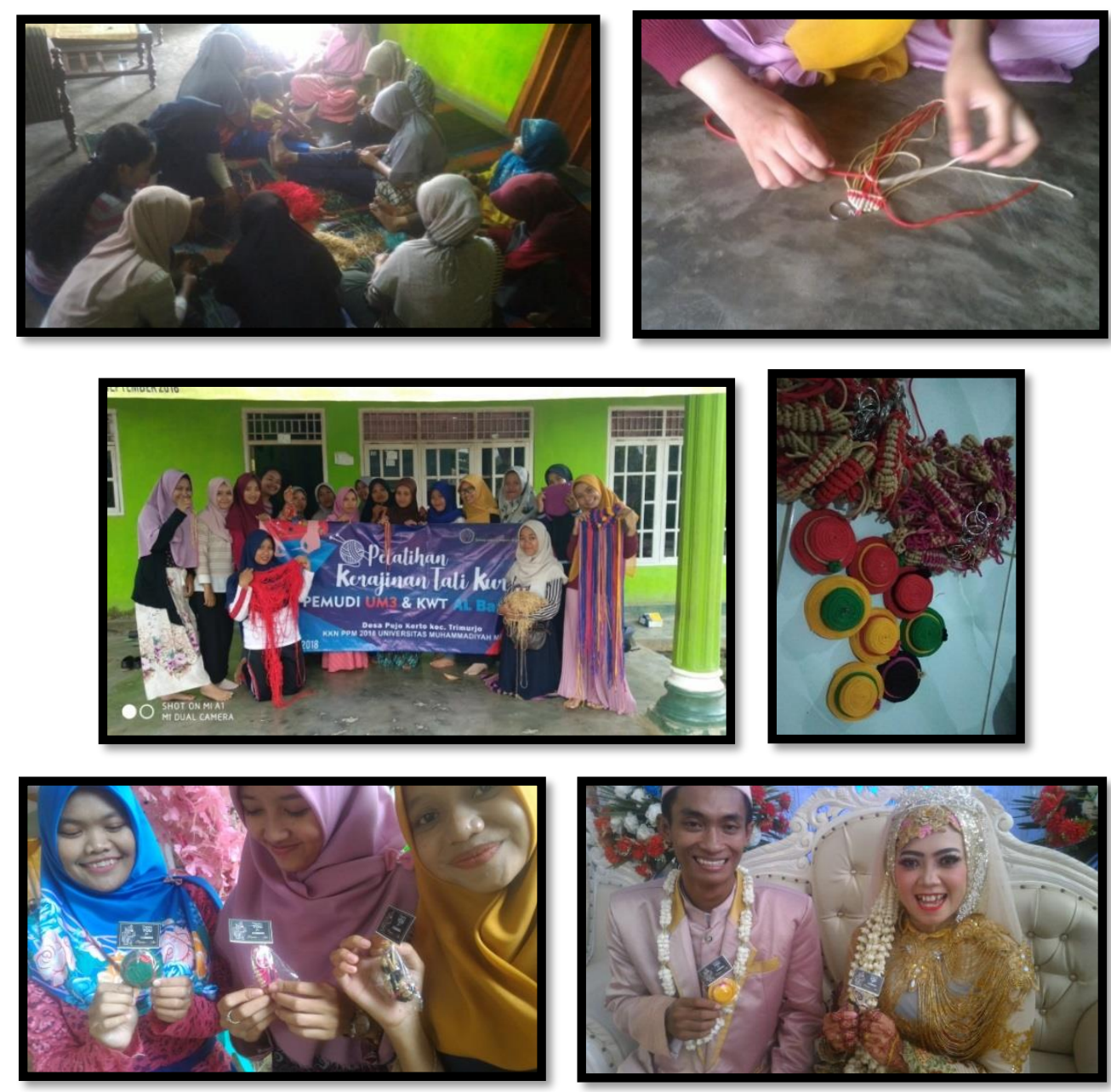

Gambar 5. Pelatihan pembuatan Tali Kur dan penjualan produk 


\section{Budidaya Pembenihan ikan lele}

Setelah merasakan bagaimana susah senangnya berwirausaha dan mendapatkan hasil dari budidaya pembesaran ikan lele, pemuda UM3 kemudian berinisiatif untuk memulai usaha pembenihan ikan lele. Inisiatif ini diusulkan oleh pemuda UM3 karena pada saat memulai usaha pemebsaran ikan lele pemuda UM3 mengalami kesulitan untk mendapatkan benih ikan lele, khususnya varietas lele mutiara yang belum banyak dibudidayakan di Kecamatan Trimurjo. Oleh karena itu, berdasarkan diskusi bersama UM3 disepakati bahwa bisnis selanjutnya yang akan dilakukan adalah usaha pembenihan ikan lele. Dari inisiatif ini, dapat diketahui bahwa insting bisnis pemuda UM3 mulai terasah dan mereka mulai mampu menangkap peluang bisnis yang ada, dan mulai berani mengambil resiko bisnis. Hal ini dikarenkan modal yang digunakan adalah sebagian dari hasil pembesaran ikan lele, dan sebagian lainnya merupakan modal dari masing-masing anggota UM3 yang berminat untuk memulai usaha pembenihan ikan lele mutiara tersebut.
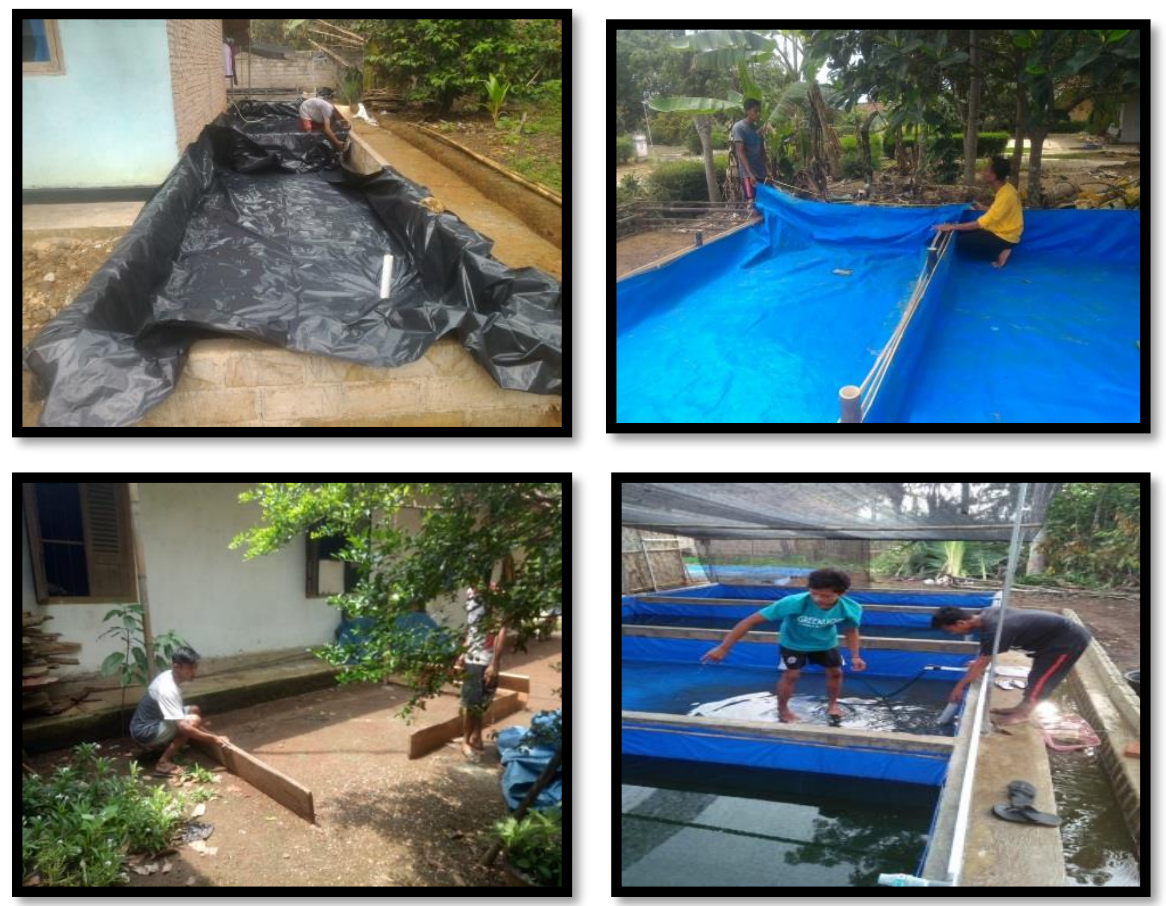

Gambar 6. Proses pembuatan dan instalasi kolam pembenihan ikan Lele Mutiara

Saat ini UM3 telah memiliki 25 plong kolam pembenihan ikan lele dengan ukuran yang bervariasi, mulai $1 \times 2$ hingg 1,5x3 meter. Dikarenakan keterbatasan biaya dan minimnya jaringan bisnis pembenihan, proses pemijahan dilakukan di kolam milik mitra UM3 yang 
berlokasi di Kota Metro. Pemuda UM3 hanya membawa ijuk sebagai media menempelnya telur ikan kepada mitra. Setelah bertelur, ijuk-ijuk tersebut dibawa pulang oleh pemuda UM3 untuk ditetaskan dan dibesarkan selama 1 bulan atau hingga ukuran benih layak dijual kepada petani pembesaran ikan lele. Penjualan benih ikan masih harus melalui mitra pemilik indukan tersebut, dikarenakan UM3 belum memiliki indukan lele Mutiara sendiri.

Setelah KKN PPM selesai dilakukan, Tim KKN PPM UM Metro masih terus melakukan pendampingan bagi UM3. Salah satunya yaitu saat ini UM3 didampingi oleh tim KKN PPM UM Metro tengah mengajukan proposal pengadaan sumur bor. Sumur bor sangat diperlukan mengingat air pada kolam pembenihan harus sering diganti untuk menjaga kesehatan benih lele yang masih rentan, sedangkan ketersediaan air sumur milik anggota UM3 tidak mencukupi.

\section{SIMPULAN}

Berdasarkan pemaparan sebelumnya diketahui bahwa melalui program KKN PPM ini terdapat peningkatan kualitas hidup masyarakat khususnya pemuda dan pemudi di Kampung Pujokerto Dusun Srimulyo, baik peningkatan di sektor ekonomi maupun sosial. Beberapa solusi yang ditawarkan untuk mengatasi permasalah yang ada, membutuhkan beberapa tahapan yang proporsional agar dapat menghadirkan solusi yang tepat guna dan tepat sasaran. Beberapa tahapan umum yang dilakukan diantaranya melalui pendekatan secara personal, FGD, pendampingan hingga evaluasi. Berikut ini adalah tabel perbandingan kondisi pemuda pemudi Dusun Srimulyo sebelum dan sesudah adanya KKN-PPM 2018:

Tabel 1: Perbandingan kondisi masyarakat sebelum dan sesudah KKN PPM

\begin{tabular}{|c|c|c|}
\hline $\mathrm{No}$ & Kondisi Sebelum & Kondisi Sesudah \\
\hline 1 & $\begin{array}{l}\text { Pemuda pemudi Dusun Srimulyo } \\
\text { kampung Pujokerto belum } \\
\text { memiliki wadah organisasi } \\
\text { kepemudaan/kewirausahaan }\end{array}$ & $\begin{array}{l}\text { Telah memiliki wadah } \\
\text { kewirausahaan bernama Usaha } \\
\text { Muda Mudi Mandiri (UM3) }\end{array}$ \\
\hline 2 & $\begin{array}{l}\text { Pemuda pemudi Kampung } \\
\text { Pujokerto belum memiliki } \\
\text { tambahan penghasilan selain } \\
\text { bertani }\end{array}$ & $\begin{array}{l}\text { - Pemuda telah memiliki usaha } \\
\text { budidaya pembesaran dan } \\
\text { pembenihan ikan lele } \\
\text { - Pemudi telah memiliki usaha } \\
\text { ketrampilan pembuatan } \\
\text { souvenir dari tali kur }\end{array}$ \\
\hline 3 & $\begin{array}{l}\text { Pemuda pemudi Kampung } \\
\text { Pujokerto tidak terbiasa } \\
\text { berorganisasi dalam forum maupun } \\
\text { di masyarakat }\end{array}$ & $\begin{array}{l}\text { Pemuda pemudi telah terbiasa } \\
\text { berorganisasi dan menyatakan } \\
\text { pendapat di dalam forum } \\
\text { kepemudaan. }\end{array}$ \\
\hline
\end{tabular}


Saran kami untuk program-program yang telah terlaksana adalah tetap melakukan pendampingan dan monitoring yang keberlanjutan mengingat seluruh program utama yang ditawarkan dan dilaksanakan benar-benar baru bagi masyarakat dusun Srimulyo Kampung Pujokerto. Harapannya, program-program yang telah dilaksanakan dapat benar-benar memberikan manfaat dan dapat diperbesar skalanya atau dapat diperluas areanya, sehingga dapat memberikan manfaat kepada pemuda pemudi di kampung lainnya.

\section{UCAPAN TERIMAKASIH}

Melalui publikasi ilmiah ini kami tidak lupa mengucapkan terima kasih kepada:

- Ristek Dikti yang telah memberikan Pendanaan melalui Hibah KKN PPM sehingga tim ini dapat melakukan pengabdian kepada masyarakat dan memberikan solusi terkait permasalah yang dihadapi oleh masyarakat.

- Universitas Muhammadiya Metro yang telah memfasilitasi dan memberikan banyak bantuan untuk kelancaran program KKN PPM 2018.

- Masyarakat Kampung Pujokerto yang telah bersedia menerima dan bekerjasama dengan Tim untuk kelancaran program KKN PPM 2018.

- Penggilingan padi di Desa Pujokerto dan Pujobasuki yang telah bersedia menjadi mitra dan banyak membantu kegiatan yang dilaksanakan oleh tim KKN PPM UM Metro 2018.

\section{DAFTAR PUSTAKA}

Nusantoro, J., Yateno, Rosid, A., (2018). Meningkatkan Daya Saing Industri Penggilingan Padi di Kampung Pujobasuki dan Pujokerto Kecamatan Trimurjo Lampung Tengah. Paper diseminarkan pada Seminar Nasional Hasil Penelitian dan Pengabdian Kepada Masyarakat. Universitas Taruma Negara. Jakarta. 7-8 September 2018.

Rosid, A., \& Sobirin, A. (2015). Memprediksi Masa Depan Perusahaan Keluarga Menggunakan Matriks Daya Tarik Industri. Paper dipresentasikan (proceeding) pada acara Seminar Nasional \& Call for Paper Fakultas Ekonomi Universitas Kristen Maranatha. Bandung 11-13 Mei 2015.

Tim PresidenRI.go.id. (2016). 2 Tahun Pemerintahan Jokowi-JK. Akselerasi Mewujudkan Indonesiasentris. Kantor Staf Presiden Republik Indonesia. Gedung Bina Graha. ISBN: 978-602-60258-0-7 